http://dx.doi.org/10.19183/how.24.2.393

\title{
From Therapy to Instruction: The Effect of Systemic Strategies on the Oral Performance of Foreign Language Learners
}

\section{De la terapia a la enseñanza: el efecto de estrategias sistémicas en el desempeño oral de estudiantes de lengua extranjera ${ }^{*}$}

\author{
Ana Clara Sánchez Solarte \\ acsanchez@udenar.edu.co \\ Universidad de Nariño, Pasto, Colombia \\ Andrés Sánchez Solarte \\ amsanchezso@unal.edu.co \\ Universidad Nacional de Colombia, Bogotá, Colombia
}

This paper reports the results of a group intervention based on strategies derived from the systemic therapy model — brief strategic therapy. These strategies aimed at decreasing the anxiety levels commonly found in oral performance tasks related to L2 learning. Thirteen students from different semesters who belonged to two foreign language teaching programs participated in four weekly 40-minute group sessions. The pre- and post-assessments suggest a meaningful reduction of anxiety levels $(t=8.978 p<0.05 ; E S=2.49)$. The results suggest that the application of the strategies is highly effective and beneficial for anxious L2 learners.

Key words: Anxiety, foreign language anxiety, intervention strategy, oral performance.

Received: December 15, 2016. Accepted: March 22, 2017.

How to cite this article (APA 6th ed.):

Sánchez Solarte, A. C., \& Sánchez Solarte, A. (2017). From therapy to instruction: The effect of systemic strategies on the oral performance of foreign language learners. HOW, 24(2), 160-178. http://dx.doi. $\operatorname{org} / 10.19183 /$ how.24.2.393.

This article is licensed under a Creative Commons Attribution-NonCommercial-NoDerivatives 4.0 International License. License Deed can be consulted at http://creativecommons.org/licenses/by-nc-nd/4.0/. 
Este artículo reporta los resultados de una intervención grupal basada en estrategias derivadas del modelo sistémico — terapia estratégica breve_ orientadas a disminuir los niveles de ansiedad encontrados en actividades orales relacionadas con el aprendizaje de una segunda lengua. Trece estudiantes de diferentes semestres de dos programas de licenciatura en lengua materna y extranjera participaron en cinco sesiones grupales con una duración aproximada de 40 minutos. Las evaluaciones pre y post revelan una disminución significativa de los niveles de ansiedad $(t=8.978 p<0.05$; ES $=2.49)$. Los resultados sugieren que la aplicación de esta estrategia es altamente efectiva y beneficiosa para los aprendices de lenguas extranjeras ansiosos.

Palabras clave: ansiedad, ansiedad asociada al aprendizaje de una lengua extranjera, desempeño oral, estrategia de intervención.

\section{Introduction}

This article reports the findings of a study carried out at a Colombian university concerning the application of psychology-based strategies to help foreign language (L2) learners face the anxiety symptoms they experience when exposed to oral performance in the L2. Second language acquisition (SLA) studies have addressed learner differences and their role in teaching and learning. These differences, including aptitude, attitude, motivation, and intelligence, determine to some extent the success in L2 learning and interact with affective factors such as anxiety (Lightbown \& Spada, 1999). Liu (2006), Liu and Jackson (2008), Liu and Ni (2015), and Krashen (as cited in Richards \& Rodgers, 2014) have discussed the role of anxiety in the performance of L2 learners. Krashen even proposed a theory of learning inside the natural approach (Richards \& Rodgers, 2001, 2014) featuring the affective filter hypothesis, which states that "acquirers with a low affective filter seek and receive more input, interact with confidence, and are more receptive to the input they receive," (Richards \& Rodgers, 2014, p. 266) implying that anxious or stressed out learners will block incoming L2 input. In community language learning, Curran (as cited in Larsen-Freeman \& Anderson, 2011) set forward principles derived from Rogerian counseling that stress the importance of dealing with learners' fears and feelings and advocating the role of teachers as counselors who foster a non-threatening learning environment to enhance language learning.

Teachers need to be aware of their potential role in triggering foreign language anxiety (FLA) and modify the input, interaction, and feedback they provide their students. As Piniel (2006) explained, FLA may be associated with the following events, all connected to teachers:

1) the teacher does not clarify why the student is being corrected, 2) the feeling of fear of being corrected by the teacher every time a mistake is made, 3) the teacher posing questions that students have not prepared for, and 4) the fast pace of the lessons. (p. 54) 
This study then, contributes to making anxiety visible among teachers and learners, and suggests procedures which enable teachers to help students successfully cope with anxietytriggering situations, increasing opportunities for L2 acquisition.

\section{Literature Review}

Anxiety is at the core of this study. It is necessary to elaborate on it to better grasp the extent of its influence on L2 learning.

\section{Understanding Anxiety}

A number of authors have offered definitions of anxiety and FLA. Abu-Rabia (2004) defines the former term simply as "fear, panic, and worry" (p. 711). Clément (as cited in Tran, 2012) sees it as "a complex construct that deals with learners' psychology in terms of their feelings, self-esteem, and self-confidence" (p. 69). Young (1992), on the other hand, characterizes FLA as an intricate psychological phenomenon particular to language learning.

For MacIntyre (as cited in Tran, 2012) and MacIntyre and Gardner (as cited in Tran, 2012), FLA is a "feeling of tension and apprehension specifically associated with second or foreign language contexts, including speaking, listening, and learning, or the worry and negative emotional reaction arousal when learning or using a second or foreign language" (p. 69). Similarly, Zhang (2001) conceives anxiety as "the psychological tension a learner goes through in performing a learning task" (p. 74). These definitions expand on the ideas set forward by Horwitz, Horwitz, and Cope (1986), for whom FLA is "a phenomenon related to but distinguishable from other specific anxieties" (p. 129) and define it as "a distinct complex construct of self-perceptions, beliefs, feelings, and behaviors related to classroom language learning arising from the uniqueness of language learning process" (p. 128). They also introduced the Foreign Language Classroom Anxiety Scale (FLCAS), an instrument to measure anxiety levels "as evidenced by negative performance expectancies and social comparisons, psychophysiological symptoms, and avoidance behaviors" (Horwitz, 1986, p. 559).

Young (1991) goes beyond defining or measuring FLA, proposing six sources of anxiety: (1) personal and interpersonal anxieties, (2) learner beliefs about language learning, (3) instructor beliefs about language teaching, (4) instructor-learner interactions, (5) classroom procedures, and (6) language testing (p. 427).

Leary (as cited in Young, 1991) summarized the manifestations of anxiety in these categories: (1) arousal-mediated responses which relate to students playing nervously with their clothes or objects, stammering, or stuttering; (2) disaffiliative behavior, which has to do with decreasing interaction or conversation with others; and (3) image protection behavior characterized by not interrupting people, smiling and nodding in a conversation. 
Beyond the specifications of this construct, a common thread can be established when defining anxiety: It relates to experiencing a paralyzing state that impacts the different functioning areas of an individual. Thus, anxiety is not a minor problem, or one limited to the private domain of a person without affecting the academic domain.

\section{Anxiety and L2 Instruction}

The L2 acquisition process encompasses tasks such as oral presentations, mock tests interviews, and improvised dialogues, answering questions without much time to prepare or rehearse that answer, interacting with students who might have a higher L2 proficiency, and monitoring and correcting one's input. All these activities, which are anxiety triggers, will also interact with teaching styles, individual resources, and previous learning experiences to generate a situation that can be managed successfully or unsuccessfully by the student. If the result is not favorable, academic achievement is compromised, self-efficacy is undermined, and self-esteem may be impoverished. The fact that the L2 learners who participated in this study will become L2 teachers is an additional reason for addressing anxiety given that their performance as students and their control (positive or negative) of anxiety-triggering situations might transfer to their professional practice. Clearly, the issue of anxiety in the L2 classroom needs to be addressed.

As Horwitz et al. (1986) state

In general, educators have two options when dealing with anxious students: 1) they can help them learn to cope with the existing anxiety provoking situation; or 2) they can make the learning context less stressful. But before either option is viable, the teacher must first acknowledge the existence of foreign language anxiety. (p. 131)

\section{Antecedents}

FLA has drawn ample research from a number of perspectives. Different authors (Casado \& Dereshiwsky, 2001; Coryell \& Clark, 2009; Kostić-Bobanović, 2009; Liu, 2006; Liu \& Jackson, 2008; MacIntyre \& Gardner, 1994a, 1994b; Tallon, 2009; von Wörde, 2003) conclude this phenomenon is a tangible reality for English as a foreign language (EFL) students at the high-school and university levels.

Other studies focus on the idea that anxiety affects language learning: Scovel (1978) provided a strong beginning, followed by Horwitz et al. (1986), and MacIntyre and Gardner $(1989,1991)$. In foreign language teaching, anxiety has been researched as an affective factor that can disrupt L2 learners' performance. Authors like Tsiplakides and Keramida (2009) have sought alternatives to help foreign language learners overcome anxiety e.g. by providing practical strategies. García Galindo (2010) studied the correlation between anxiety and 
foreign language learning, questioning the role of teachers as a main part of the teaching and learning process, placing learners as the main agent in the classroom instead. Lightbown and Spada (1999) discussed learner differences and the affective factors that can influence the teaching and learning process, whereas MacIntyre and Gardner (1989, 1991), Sheen (2008), and Huang and Hung (2012) explored the effects of anxiety concluding that learners who display high anxiety levels are less likely to participate in learning activities, attaining lower performance levels than non-anxious peers. Horwitz (2001) attempted to clarify the link between L2 learning and anxiety by reviewing the existing literature, concluding that anxiety does cause poor language learning in some students. Finally, Gurzynski-Weiss and Révész (2012), Moskovsky, Alrabai, Paolini, and Ratcheva (2013) have implied that an increase in motivation correlates negatively with learning anxiety and performance anxiety.

The literature related to anxiety explains that it indeed affects language learning. Anxiety levels are inversely proportional to the quality of an individual's performance. That is, anxious learners display less motivation towards academic tasks and less achievement in contrast to non-anxious peers (Huang \& Hung, 2012; Sheen, 2008; Tsiplakides \& Keramida, 2009).

Psychology has also contributed to the intervention on anxiety with the works of Nardone (1995); Watzlawick, Weakland, and Fisch (1974); and Watzlawick, BeavinBavelas, and Jackson (1997). Clément, Gardner, and Smythe (1980) carried out a study with L2 university students which implied a possible relationship between integrative motive and self-confidence. Horwitz (2001) and Onwuegbuzie, Bailey, and Daley (1999) explored seven factors associated with FLA (e.g., self-esteem, self-concept) and L2 study concluding that anxiety is a predictor of L2 achievement. Tran (2012) explains that MacIntyre and Gardner used eleven anxiety scales "to examine the relationship between the dimensions of anxiety and the various measures of learning and production" (p. 70), finding that communicative anxiety does play a role in the acquisition and production of French vocabulary.

This framework supports the design and application of intervention strategies tailored for the L2 classroom while psychology provides a basis for them setting forward intervention models, mainly at individual levels (Bögels et al., 2010). Among these models, motivational strategies are effective in boosting student achievement and can be useful for anxious L2 learners. Gradual exposure and paradoxical strategies of systemic thinking also provide an intervention strategy for groups, a strategy that displays notable results (Nardone, 1995; Watzlawick et al., 1974; Watzlawick et al., 1997). In a systemic model, past causes or intrinsic features of an individual are not examined in order to generate a change in the situation causing discomfort. It rather explores the interaction between the actions and the effects of what people do to solve said situation. In this sense, the logic of the designed intervention has a paradoxical nature: The idea is not to suppress anxiety, but exacerbate it until it causes saturation. 


\section{Method}

In this study, a quasi-experimental, intra-subject design was used. The purpose was to establish if a brief group intervention in the classroom context would significantly reduce the anxiety levels associated with oral performance displayed by foreign language learners.

\section{Participants}

The study was conducted in the context of two undergraduate foreign language teacher education programs at a public university in Colombia and involved thirteen students, who come from a middle-class background. There were ten women (age $\bar{x}: 19.8 s d=5.41)$ and three men (age $\bar{x}: 20.3 s d=3.05$ ). Six of these students belonged to second semester, five of them to third semester, one of them to fifth semester, and one of them to ninth semester.

\section{Procedure}

The thirteen participants were divided into two groups since the two teaching programs have different schedules: The English-French program students attended classes in the morning while the English-Spanish program students did it in the evening. Each group met with the workshop leader once a week for four weeks plus one follow-up session. For each session, a highly-structured guide including objectives, strategies, and specific tasks and recommendations for the workshop leader who was training the participants was created. The first session started with a quantitative form of data collection: the administration of the FLCAS (see Appendix 1) in order to identify a baseline anxiety level. Before working with the group, the workshop leader was trained by the psychologist to guide the participants and be prepared for their potential reactions to the intervention. The day before the workshops, additional training took place to solve questions and clarify doubts. Each session began asking the participants how they experienced anxiety during that week and which were the effects of the tasks carried out in the last session and afterwards. Subsequently, the workshop leader introduced the task for that session. The aim of the first two sessions was to exacerbate the participants' anxiety levels using visual imagery related to their classroom-related fears, reliving an anxiety-triggering situation and its symptoms in as much detail as possible, and surrendering to the experience by expressing their feelings. They were instructed to do the same every day, with the same experience, until the next meeting (see Appendix 2). The same was done in the second session. In the third and fourth sessions, the researchers encouraged learners to revisit activities and spaces that had been abandoned due to their potential to produce anxiety. Additionally, in the third session the students were instructed to apply metacognitive and affective strategies (Oxford, 1990, 1999) to be better prepared for interacting in the L2 and face oral presentations and tests more efficiently. Students were instructed to choose a specific place and time to study and anticipate questions that might 
be asked in class, practice deep breathing, apply positive self-talk, and praise themselves after they faced an anxiety-triggering experience. After the workshops were completed, the FLCAS was administered again and qualitative data were collected: The groups met again to share their insights and conclusions about the process and evaluate the intervention.

Recruitment. The researchers announced the initiation of the project in different courses. Students who were interested approached them voluntarily and a meeting took place in order to define the participants. In accordance with procedures of the ethical committee of the university, the students accepted participation in the study by signing an informed consent which made explicit the purpose of the intervention, the duration of the workshops, and the fact that they could quit the study at any given point in the process without any negative consequences. Subsequently the thirteen participants completed a semi-structured interview carried out by one of the main researchers. This interview elicited information about which participants were actually affected by anxiety-related symptoms and could thus benefit from the intervention. Finally, every participant was assigned a code in order to ensure anonymity and confidentiality.

Intervention. The participants and the workshop leader met five times. Each meeting lasted about 40 minutes and there were no more than 10 people in the group, so the learners did not feel overwhelmed. The sessions were conducted in the learners' first language to avoid triggering anxiety symptoms. The workshop was created by a clinical psychologist based on an existing protocol for the individual treatment of phobia and panic attacks (Nardone, 2004) and focused on making learners aware of the need to stop avoiding anxiety symptoms since the relief avoidance produces is temporary and, in the long run, reinforces the need to avoid anxiety evoking situations. The intervention consisted of the imaginary and exaggerated exposure to the feared events, and on taking small risks associated with the fears in a progressive way along the four weekly encounters. In the final session, the participants received an additional tool to keep on facing situations that were avoided before and the impact of the intervention was evaluated.

Instruments. In order to measure the effects of the intervention, the FLCAS was applied in the fifth session. This instrument, designed by Horwitz et al. (1986), aims at measuring a specific type of anxiety linked to the foreign language classroom. The instrument has 33 items with a five-point Likert scale and encompasses three anxiety types: test anxiety, speech anxiety, and communication apprehension. The intervention addressed all three categories since learners reported that oral exams, presentations, and interaction with their classmates triggered the same anxiety symptoms. The scores on this scale range from 33 to 165 and higher scores mean higher levels of foreign language anxiety experienced. Since there was not an available version of the FLCAS in Spanish, a linguistic adaptation had to be done. Two researchers with a degree in translation, two L2 teachers, and four students worked separately translating the 33 items. These versions were compared to find commonalities. Once the 
final version in Spanish was translated by a psychologist and the text was corrected, the instrument was administered. The qualitative data were collected by means of an essay. The prompt asked learners to describe their feelings about their performance, the results of the experience, and their outlook on their future reactions towards anxiety-triggering situations.

\section{Findlings}

\section{2uantitative Findings}

In this study, a transversal design of pre- and post-repeated measures was used. The participants completed the FLCAS scale in the first and last meeting in order to register any changes in the anxiety levels experienced when performing orally in a foreign language (English or French). The data shown in Figure 1 suggests that the post intervention FLA levels in the participants are significantly lower than before the treatment.

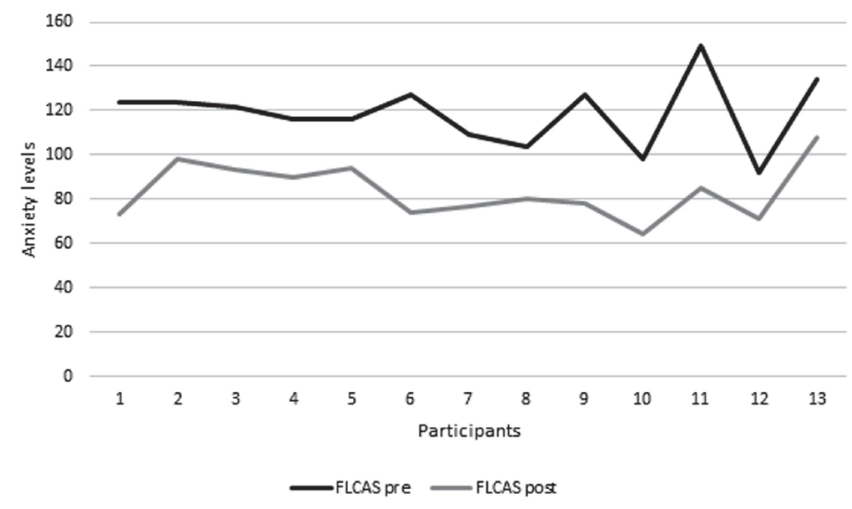

Figure 1. Pre-Post Intervention Anxiety Levels

Considering the number of cases $(n=13)$ and the normality in the distribution of the data (test Sahpiro-Wilik $=.940$ for the pre- and .894 for the post-intervention), a dependent $t$-test was carried out in order to verify this change (Table 1$)$. This analysis revealed meaningful differences between the pre- and post-FCLAS scores in all the participants in this study $(t=8.978 p<0.05)$. Also, a Cohen's $d$ was calculated in order to determine the magnitude of the difference observed between the samples. A large effect size ( $E S=2.49)$ was found. Anxiety levels reported by the participants are significantly lower in the post measures and the effect has a considerable size. Both the FLCAS scores and the self-reported qualitative data described in the next section support the efficacy of the intervention. 
Table 1. t-Student Test in the Pre- and Post-Intervention Measurements

\begin{tabular}{|c|c|c|c|c|c|c|c|c|c|}
\hline & & \multicolumn{5}{|c|}{ Paired differences } & \multirow{3}{*}{$t$} & \multirow{3}{*}{$g l$} & \multirow{3}{*}{$\begin{array}{c}\text { Sig. } \\
\text { (bilateral) }\end{array}$} \\
\hline & & \multirow[t]{2}{*}{ Mean } & \multirow[t]{2}{*}{$\begin{array}{l}\text { Standard } \\
\text { deviation }\end{array}$} & \multirow{2}{*}{$\begin{array}{l}\text { Average } \\
\text { standard } \\
\text { error }\end{array}$} & \multicolumn{2}{|c|}{$\begin{array}{l}95 \% \text { confidence } \\
\text { interval of the } \\
\text { difference }\end{array}$} & & & \\
\hline & & & & & Inferior & Superior & & & \\
\hline $\begin{array}{c}\text { Par } \\
1\end{array}$ & $\begin{array}{l}\text { PRE - } \\
\text { POST }\end{array}$ & 35.15385 & 14.11764 & 3.91553 & 26.62264 & 43.68505 & 8.978 & 12 & .000 \\
\hline
\end{tabular}

\section{Qualitative Findings}

In order to gain a wider view of the issue, the final comments and essays provided by the participants were classified. The findings indicate that all participants perceived the strategies as useful for their academic and personal lives and for dealing with test anxiety, speech anxiety, and communication apprehension. Again, the comments were written in Spanish so the participants could accurately express their opinions about the experience. Here are the comments translated by the two researchers and organized in three categories: feeling about their performance, results of the experience, and outlook on their future reactions. ${ }^{1}$

Feelings about their performance. All the participants recognized that their feelings of self-efficacy were enhanced by the strategies applied in the workshops.

I am grateful for this method that was shared in these sessions since without them I would not feel this good when expressing myself or speaking in public.

I think these projects will help many people who, due to their fear to face anxiety, are missing opportunities. These workshops will practically give their lives back to the people who take them.

Thanks to the steps I took to reach my goal, I realize that I am capable of speaking clearly in front of my classmates, and I can feel sure that what I studied is right, and if I get corrected, it will help me advance my learning.

I never thought I would perform excellently with a native speaker, I have improved and I made progress in my abilities of comprehension and expression, which allow me to perform favorably in different areas.

Results of the experience. None of the participants reported that their symptoms had worsened after doing the assigned tasks and facing their fears. In fact, they reported feeling satisfied with that experience.

Translation made for publication purposes 
The satisfaction I feel is that I can overcome this fear when I have to face different situations and in that way, get good results and self-confidence.

All the participants stated that they observed a change in their behavior and response towards anxiety symptoms.

I could notice very positive changes in my behavior when facing some of my fears and I overcame them little by little.

Working as a "community" of students who were experiencing similar symptoms and experiences concerning anxiety was also perceived as a positive result.

Sharing with other young people each session and sharing and expressing the ideas and opinions we had was a very good experience.

Outlook on their future reactions. The participants' comments revealed they were satisfied with the strategies and with their immediate application in the oral presentations they had to face during and after the intervention.

I feel more confident and control more my physical emotions like shaking, and the mental ones like avoiding the facing of fear.

I have felt improvement and have felt more confident when doing presentations following the steps and think that now it is easier for me to face participation and presentations.

They also expressed satisfaction with the metalinguistic strategies provided, but it is important to remark that they did not feel as if this was a panacea. They know they need to continue applying the strategies in the near future, but feel more confident now since they have tools to work around future anxiety-triggering situations, making the positive results of the intervention relevant. Balemir, Heng, Abdullah, and Yusof; and Saltan (as cited in Çagatay, 2015) highlight the importance of addressing anxiety:

...even the moderate level of this anxiety is alarming and needs to be dealt with [with] care. This level might seem acceptable at first glance; however, this affective problem could discourage students from expressing their thoughts in English, affect their willingness to communicate (Wu \& Lin, 2014) and hinder the development of communicative competence in the long run. (p. 654)

\section{Conclusions}

This study is an initial exploration of how a psychology-based strategy can be brought into the L2 classroom to mitigate FLA and help learners perform orally in the L2. The conclusions drawn from this experience are: 
FLA is linked to foreign language proficiency. There is a negative correlation between L2 learning and FLA as the latter hinders L2 learning and its impact spreads beyond the classroom. This echoes the findings of authors like Huang and Hung (2012), Onwuegbuzie et al. (1999), among others.

The application of a psychology-based intervention strategy as evidenced by the qualitative and quantitative findings is effective in supporting students who are dealing with FLA manifestations of learners of English and French as a foreign language at Universidad de Nariño (Colombia) in the areas of test anxiety, speech anxiety and communication apprehension.

FLA is not something learners can overcome without support, and this study has pedagogical implications.

Given that the intervention is efficient and does not require an extended time period for its application, it is susceptible to being included in the curricular activities of college students as a strategy to prevent students from dropping out of school.

FLA can be difficult to detect simply by interacting or observing lessons due to the prevailing avoidance on the part of learners or the misleading symptoms. Anxiety, as shown by the qualitative data provided by the participants, might be perceived by teachers as lack of interest, lack of preparation, laziness, or indifference. Thus, it is necessary to apply an instrument such as the FLCAS in order to determine anxiety levels reliably.

Teachers need to back learners by implementing group work, selective error correction, and activities with a focus on meaning, real content, and functions (Sato, 2003). Jigsaw activities, project-based learning, and cooperative language learning are alternatives that might be used in L2 instruction to foster oral performance and decrease anxiety among learners.

Anxiety is a serious issue in SLA with concrete consequences as the ones reported by the participants. Therefore, it should not be taken lightly by teachers. The most prevailing consequences of FLA among the L2 learners participating in the study have different manifestations: Learners isolate themselves because their classmates refuse to work with them in anticipation of their poor or limited oral performance in the L2. Also, learners stop attending certain courses given their impossibility to overcome their symptoms and the fact that, initially, avoidance makes them feel better.

Teachers need to pay attention to avoidance. The participants reported that another consequence of not addressing FLA was not taking tests, knowing that avoiding that particular test might mean failing a course. Another result of anxiety or rather a symptom evidencing its existence was that some participants would get physically ill to avoid going to a certain class or session when they knew they had to perform orally in the L2. One final effect of FLA 
on learners is the reluctance to participate in class even if it means being labeled negatively by the teacher (e.g., this student is lazy, this student is uninterested) or by their peers.

Besides the intervention strategies described in this study, the explicit instruction on the application of metacognitive and affective strategies such as those suggested by Oxford (as cited in Tasmini, 2009) including "deep breathing, laughter, positive self talk (e.g., I know I can do it!), praising oneself for performance” (p. 122), or using a language learning diary to record feelings about language learning are effective additional resources to help learners cope with FLA symptoms.

\section{Limitations of the Study}

The limitations of the study are related to three main elements: First, a control group was not included, which restricts the generalizability of the results, but does not undermine the internal validity and efficacy of the observed changes in the sample, due to the repeated measures design used. Second, the strategy was not applied to a large group. The results obtained might vary if the sample consisted of 30 or 40 students. Additionally, the strategy focused on helping foreign language learners with performance anxiety, without considering possible correlations with factors such as low language proficiency or low practice.

\section{Directions for Future Research}

In order to address the limitations of the current study, future research may include a control group or an examination of other potential factors. Future studies related to FLA may also consider its interaction with other types of anxiety, such as social anxiety, in order to design different intervention strategies. Exploring the relationship between anxiety and other language skills and components such as writing or grammar is also recommended.

\section{References}

Abu-Rabia, S. (2004). Teachers' role, learners' gender differences, and FL anxiety among seventh grade students studying English as a FL. Educational Psychology, 24(5), 711-721. http://doi.org /10.1080/0144341042000263006.

Bögels, S. M., Alden, L., Beidel, D. C., Clark, L. A., Pine, D. S., Stein, M. B., \& Voncken, M. (2010). Social anxiety disorder: Questions and answers for the DSM-V. Depression and Anxiety, 27(2), 168-189. http://doi.org/10.1002/da.20670.

Çagatay, S. (2015). Examining EFL students' foreign language speaking anxiety: The case at a Turkish state university. Procedia: Social and Behavioral Sciences, 199(3), 648-656. http://doi. org/10.1016/j.sbspro.2015.07.594. 
Casado, M. A., \& Dereshiwsky, M. I. (2001). Foreign language anxiety of university students. College Student Journal, 35(4), 539-551.

Clément, R., Gardner, R. C., \& Smythe, P. C. (1980). Social and individual factors in second language acquisition: A study of francophones learning English. Canadian Journal of Behavioural Science, 12(4), 293-302. http://doi.org/10.1037/h0081081.

Coryell, J. E., \& Clark, M. C. (2009). One right way, intercultural participation, and language learning anxiety: A qualitative analysis of adult online heritage and nonheritage language learners. Foreign Language Annals, 42(3), 483-504. http://doi.org/10.1111/j.1944-9720.2009.01037.x.

García Galindo, G. (2010). La ansiedad ante el aprendizaje de una segunda lengua [Anxiety in second language learning]. Autodidacta: Revista de la Educación en Extremadura. Retrieved from http:/ / www.anpebadajoz.es/autodidacta/autodidacta_archivos/numero_5_archivos/4_g_g_galindo.pdf.

Gurzynski-Weiss, L., \& Révész, A. (2012). Tasks, teacher feedback, and learner modified output in naturally occurring classroom interaction. Language Learning, 62(3), 851-879. http://doi. org/10.1111/j.1467-9922.2012.00716.x.

Horwitz, E. K. (1986). Preliminary evidence for the reliability and validity of a foreign language anxiety scale. TESOL Quarterly, 20(3), 559-562. http://doi.org/10.2307/3586302.

Horwitz, E. K. (2001). Language anxiety and achievement. Annual Review of Applied Linguistics, 21, 112-127. http://dx.doi.org/10.1017/S0267190501000071.

Horwitz, E. K., Horwitz, M. B., \& Cope, J. (1986). Foreign language classroom anxiety. The Modern Language Journal, 70(2), 125-132. http://doi.org/10.1111/j.1540-4781.1986.tb05256.x.

Huang, H.-T. D., \& Hung, S.-T. A. (2012). Comparing the effects of test anxiety on independent and integrated speaking test performance. TESOL Quarterly, 47(2), 244-269. http:/ /doi. org/10.1002/tesq.69.

Kostić-Bobanović, M. (2009). Foreign language anxiety of university students. Economic Research, 22(3), 47-54.

Larsen-Freeman, D., \& Anderson, M. (2011). Techniques and principles in language teaching (3rd ed.). Oxford, UK: Oxford University Press.

Lightbown, P. M., \& Spada, N. (1999). How languages are learned (2nd ed.). Oxford, UK: Oxford University Press.

Liu, M. (2006). Anxiety in EFL classrooms: Causes and consequences. TESL Reporter, 39(1), 1332.

Liu, M., \& Jackson, J. (2008). An exploration of Chinese EFL learners' unwillingness to communicate and foreign language anxiety. The Modern Language Journal, 92(1), 71-86. http:/ /dx.doi. org/10.1111/j.1540-4781.2008.00687.x.

Liu, M., \& Ni, H. (2015). Chinese university EFL learners' foreign language writing anxiety: Pattern, effect and causes. English Language Teaching, 8(3), 46-58. http://dx.doi.org/10.5539/elt. v8n3p46. 
MacIntyre, P. D., \& Gardner, R. C. (1989). Anxiety and second-language learning: Toward a theoretical clarification. Language learning, 39(2), 251-275. http://doi.org/10.1111/j.1467-1770.1989. tb00423.x.

MacIntyre, P. D., \& Gardner, R. C. (1991). Language anxiety: Its relation to other anxieties and to processing in native and second languages. Language Learning, 41(4), 513-534. http:/ /doi. org/10.1111/j.1467-1770.1991.tb00691.x.

MacIntyre, P. D., \& Gardner, R. C. (1994a). The effects of induced anxiety on three stages of cognitive processing in computerized vocabulary learning. Studies in Second Language Acquisition, 16(1), 1-17. http://dx.doi.org/10.1017/S0272263100012560.

MacIntyre, P. D., \& Gardner, R. C. (1994b). The subtle effects of language anxiety on cognitive processing in the second language. Language Learning, 44(2), 283-305. http://doi. org/10.1111/j.1467-1770.1994.tb01103.x.

Moskovsky, C., Alrabai, F., Paolini, S., \& Ratcheva, S. (2013). The effects of teachers' motivational strategies on learner's motivation: A controlled investigation of second language acquisition. Language learning, 63(1), 34-62. http://doi.org/10.1111/j.1467-9922.2012.00717.x

Nardone, G. (1995). Miedo, pánico y fobias [Fear, panic, and phobias]. Barcelona, ES: Herder.

Nardone, G. (2004). No hay noche que no vea el día [There is no night in which you don't see the day]. Barcelona, ES: Herder.

Onwuegbuzie, A. J., Bailey, P., \& Daley, C. E. (1999). Factors associated with foreign language anxiety. Applied Psycholinguistics, 20(2), 217-239. http://doi.org/10.1017/S0142716499002039.

Oxford, R. L. (1990). Language learning strategies: What every teacher should know. New York, US: Heinle.

Oxford, R. L. (1999). Anxiety and the language learner: New insights. In J. Arnold (Ed.), Affect in language learning (pp. 58-67). Cambridge, UK: Cambridge University Press.

Piniel, K. (2006). Foreign language classroom anxiety: A classroom perspective. In M. Nikolov \& J. Horváth (Eds.), UPRT 2006: Empirical studies in English applied linguistics (pp. 39-58). Pécs, HU: Lingua Franca Csoport.

Richards, J. C., \& Rodgers, T. S. (2001). Approaches and methods in language teaching (2nd ed.). New York, US: Cambridge University Press. http://doi.org/10.1017/CBO9780511667305.

Richards, J. C., \& Rodgers, T. S. (2014). Approaches and methods in language teaching (3rd ed.). New York, US: Cambridge University Press.

Sato, K. (2003). Improving our students' speaking skills: Using selective error correction and group work to reduce anxiety and encourage real communication. Retrieved from ERIC database. (ED475518)

Scovel, T. (1978). The effect of affect on foreign language learning: A review of the anxiety research. Language learning, 28(1), 129-142. http://doi.org/10.1111/j.1467-1770.1978. tb00309.x.

Sheen, Y. (2008). Recasts, language anxiety, modified output and L2 learning. Language Learning, 58(4), 835-874. 
Tallon, M. (2009). Foreign language anxiety and heritage students of Spanish: A quantitative study. Foreign Language Annals, 42(1), 112-137. http:/ / dx.doi.org/10.1111/j.1944-9720.2009.01011.x.

Tasnimi, M. (2009). Affective factors: Anxiety. Journal of Pan-Pacific Association of Applied Linguistics, 13(2), 117-124.

Tran, T. T. T. (2012). A review of Horwitz, Horwitz, and Cope's theory of foreign language Anxiety and the challenges to the theory. English Language Teaching, 5(1) 69-75.

Tsiplakides, I., \& Keramida, A. (2009). Helping students overcome foreign language speaking anxiety in the English classroom: Theoretical issues and practical recommendations. International Education Studies, 2(4), 39-44. http://doi.org/10.5539/ies.v2n4p39.

von Wörde, R. A. (2003). Students' perspectives on foreign language anxiety. Inquiry, 8(1). Retrieved from http:// files.eric.ed.gov/fulltext/EJ876838.pdf.

Watzlawick, P., Weakland, J. H., \& Fisch, R. (1974). Change: Principles of problem formation and problem resolution. New York, US: Norton.

Watzlawick, P., Beavin-Bavelas, J., \& Jackson, D. D. (1997). Teoría de la comunicación bumana [Theory of human communication] (11th ed.). Barcelona, ES: Editorial Herder.

Young, D. J. (1991). Creating a low-anxiety classroom environment: What does the language anxiety research suggest? The Modern Language Journal, 75(4), 426-439. http://doi. org/10.1111/j.1540-4781.1991.tb05378.x.

Young, D. J. (1992). Language anxiety from the foreign language specialist's perspective: Interviews with Krashen, Omaggio, Hadley, Terrell, and Rardin. Foreign Language Annals, 25(2), 157-172. http://dx.doi.org/10.1111/j.1944-9720.1992.tb00524.x.

Zhang, L. J. (2001). Exploring variability in language anxiety: Two groups of PRC students learning ESL in Singapore. RELC Journal, 32(1), 73-94. http://dx.doi.org/10.1177/ 003368820103200105.

\section{The Authors}

Ana Clara Sánchez Solarte holds an MA in TESOL/Linguistics from The University of Northern Iowa. She is the director of the Lenguaje y Pedagogía research group at Universidad de Nariño. Her interests include L2 methodology, classroom management, and affective factors in foreign language learning.

Andrés Sánchez Solarte holds a degree in Clinical Psychology from Universidad Nacional de Colombia, and a specialization in systemic therapy from Escuela Sistémica de Argentina. He is currently studying for an MA in Psychology at Universidad Nacional de Colombia. 


\section{Appendix 1: FLCAS (Foreign Language Classroom Anxiety Scale, Horwitz et al., 1986)}

Name: Age: Gender: $\mathrm{M} \_$F

Below you will find a series of statements regarding your feelings or the situations that may take place in your foreign language class. Please, state your degree of agreement or disagreement with the statement marking: strongly agree, agree, neither agree nor disagree, disagree or strongly disagree.

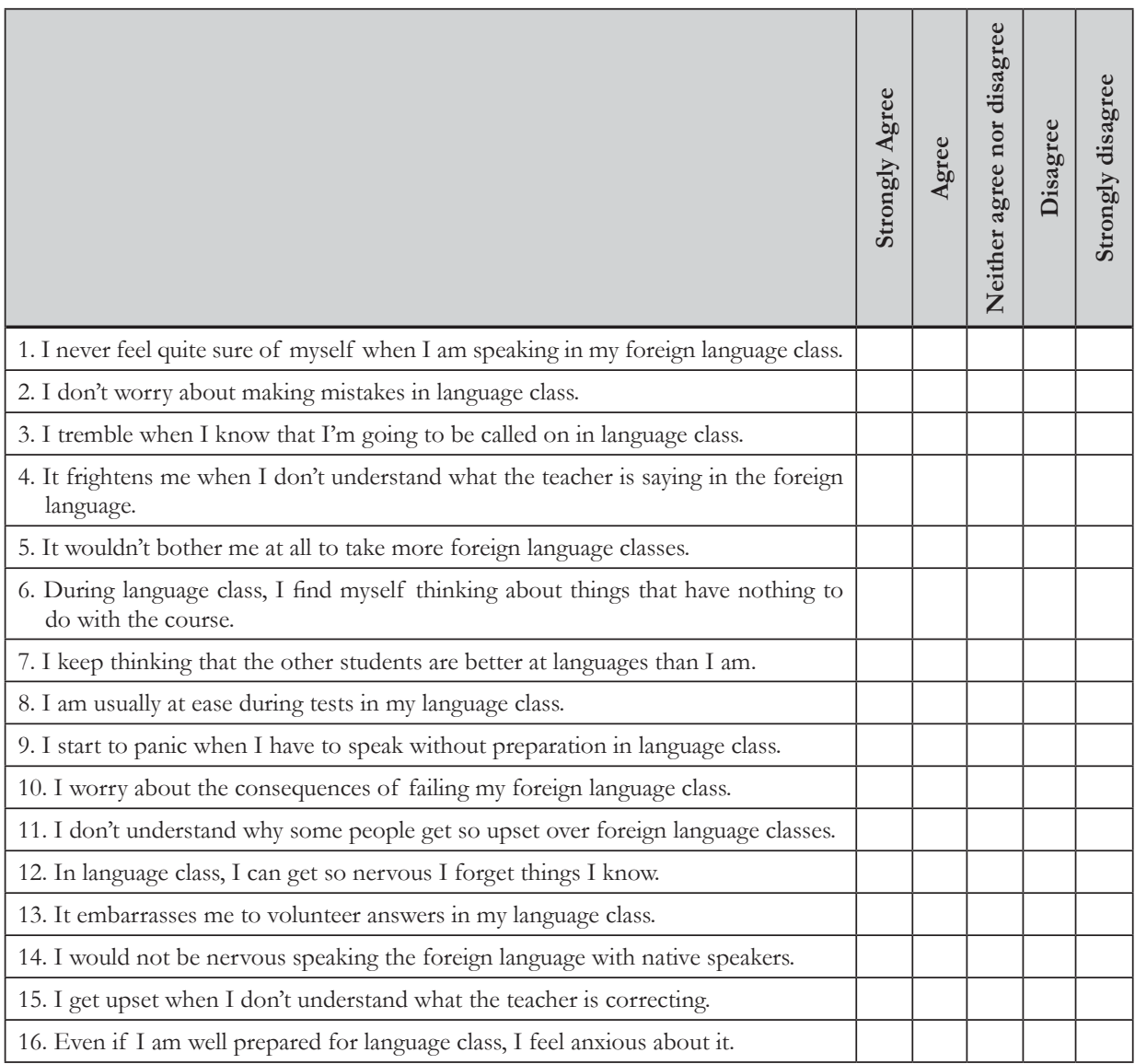




\begin{tabular}{|c|c|c|c|c|c|}
\hline & 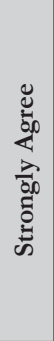 & 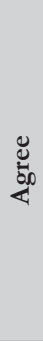 & 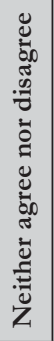 & 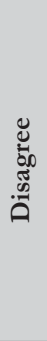 & 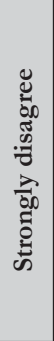 \\
\hline 17. I often feel like not going to my language class. & & & & & \\
\hline 18. I feel confident when I speak in foreign language class. & & & & & \\
\hline 19. I am afraid that my language teacher is ready to correct every mistake I make. & & & & & \\
\hline 20. I can feel my heart pounding when I'm going to be called on in language class. & & & & & \\
\hline 21. The more I study for a language test, the more confused I get. & & & & & \\
\hline 22. I don't feel pressure to prepare very well for language class. & & & & & \\
\hline 23. I always feel that the other students speak the foreign language better than I do. & & & & & \\
\hline $\begin{array}{l}\text { 24. I feel very self-conscious about speaking the foreign language in front of other } \\
\text { students. }\end{array}$ & & & & & \\
\hline 25. Language class moves so quickly I worry about getting left behind. & & & & & \\
\hline 26. I feel more tense and nervous in my language class than in my other classes. & & & & & \\
\hline 27. I get nervous and confused when I am speaking in my language class. & & & & & \\
\hline 28. When I'm on my way to language class, I feel very sure and relaxed. & & & & & \\
\hline 29. I get nervous when I don't understand every word the language teacher says. & & & & & \\
\hline $\begin{array}{l}\text { 30. I feel overwhelmed by the number of rules you have to learn to speak a foreign } \\
\text { language. }\end{array}$ & & & & & \\
\hline $\begin{array}{l}\text { 31. I am afraid that the other students will laugh at me when I speak the foreign } \\
\text { language. }\end{array}$ & & & & & \\
\hline $\begin{array}{l}\text { 32. I would probably feel comfortable around native speakers of the foreign } \\
\text { language. }\end{array}$ & & & & & \\
\hline $\begin{array}{l}\text { 33. I get nervous when the language teacher asks questions which I haven't prepared } \\
\text { in advance. }\end{array}$ & & & & & \\
\hline
\end{tabular}




\section{Appendix 2: Guide Workshop 1}

\section{Objectives:}

1. To acknowledge anxiety-related experiences and the unsuccessful strategies used by the group of participants in order to face anxiety.

2. To carry out an experiential exercise where the participants can realize the paradoxical nature of anxiety.

\section{Questions:}

- Question 1. When you are in a foreign language class and you have to speak, how do you feel? How does the fear manifest itself? (The workshop leader needs to validate the answers with empathy).

- Question 2. When you have to perform in the foreign language or you have to participate orally in class and anxiety manifests itself, what do you do? Do you face the situation or do you avoid it? (Most participants might avoid it. If they say they face it, one can ask them how they do it and why that solution has not been satisfactory).

- Question 3. It is clear that most of you, when faced with fear or anxiety, choose to avoid the situation. Now I want you to tell me in detail how do you avoid it? (Each participant must express the avoidance strategies they use). The workshop leader may elicit answers asking, for instance, "Has it ever happened to you that you would rather ask one of your peers to present and do another part of the work instead? Well, that is an avoidance strategy".

- Question 4. In your opinion, when you avoid performing orally in the foreign language, do you feel better or does your fear increase? (It is expected that most of the participants will say they feel better. If the answer is that they feel worse, they will then acknowledge the way they are contributing to the problem).

- Restructuring: "If I have understood correctly, every time you avoid presenting, interacting, or participating in class, you feel relieved...but sooner or later that fear comes back and with time it has grown even more ..." (Pause for a few seconds) "I am not going to ask you to stop avoiding the situation because clearly at this point in time, you cannot do it... However, I want you to think that every time you avoid your fear, you get two things: the first and most obvious one is that you feel relieved. The second, subtler and destructive one is that you confirm your inability to face 
the situation and this makes the fear grow more and more... and more...As someone once said: "I carry with me the wounds of all the battles I have avoided." And I add, "The wounds from avoided battles never heal, they never stop bleeding".

\section{Task:}

- The workshop leader sets an alarm clock to go off 25 minutes later. The participants can see this. "Now, please close your eyes and listen carefully. It is simple, just listen and do not write anything down. Close your eyes. Imagine you are in front of the class; with the teacher you fear the most. (Here, some descriptions the participants provided in Question 1 "How is fear manifested")... you feel your heart beats fast, your hands are sweaty, you feel panic, you cannot speak, etc. Think the most fearful, agitating, disturbing, anxiety-provoking thoughts and do whatever you feel like doing: if you want to scream, scream. If you want to cry, cry but when the alarm goes off, stop. It will be over. You will leave this classroom and you will carry on your day normally. The most important thing is that in this span of 25 minutes you experience the worst fantasies regarding your situation and do what you need to do. I suggest you stay there until the alarm goes off; it does not matter if you achieve feeling bad or not; if you can think or not; you will stay there trying to feel the worst inside your worst possible fantasies. Once the alarm goes off, it will be over."

- "All right, open your eyes". (Give them a few seconds to be totally awake) "How did it go? Could you relive the sensations, the fear you described?" Regardless of the fact that they did it or not, they are told this: "OK, let us see how this goes along the week. From now until our next meeting, every day early in the morning after lunch or at night, go to your room or a room in your house where you will not be interrupted. Close the curtains or turn the lights off, get yourself comfortable, relax, set up an alarm to go off after 25 minutes and in those 25 minutes, purposefully, think of the worst fantasies about the situation in the exact way we did today. 25 minutes every day without exceptions". 